\title{
Tea Consumption and Risk of Type 2 Diabetes: A Meta-Analysis of Cohort Studies
}

\author{
Yali Jing, $M D^{7}$, Guanjun Han, $M D^{7}$, Yun $H u, M D^{2}$, Yan Bi, MD, PhD², Lirong Li, MD, PhD, \\ and Dalong Zhu, MD, $P h D^{1}$
}

'Department of Endocrinology, Drum Tower Clinical Medical College of Nanjing Medical University, Nanjing, Jiangsu Province, China;

${ }^{2}$ Department of Endocrinology, Affiliated Drum Tower Hospital, Medical College of Nanjing University, Nanjing, Jiangsu Province, China.

\begin{abstract}
BACKGROUND: Tea consumption has been extensively studied in relation to various diseases, several epidemiologic studies have been performed to investigate the association of tea consumption with type 2 diabetes; however, the results of these studies were not entirely consistent.
\end{abstract}

OBJECTIVE: To conduct a meta-analysis of studies that assessed the association of tea consumption and the risk of type 2 diabetes.

RESEARCH DESIGN AND METHODS: We performed a systematic literature search through November 2008 in PUBMED, MEDLINE, EMBASE, and Cochrane Database of Systematic Reviews. The search was limited to Englishlanguage studies. Studies were excluded if they were type 1 diabetes, animal studies. Nine cohort studies were identified by two authors, and summary relative risks (RRs) were calculated using a random-effects model.

RESULTS: We identified nine cohort studies, including 324,141 participants and 11,400 incident cases of type 2 diabetes with follow-up ranging from 5 to 18 years. The summary adjusted RR did not show that tea consumption was associated with a reduced type 2 diabetes risk (RR, 0.96; 95\% confidence interval (CI), 0.92-1.01). Evidence from the results of our stratified analyses revealed that tea consumption $\geq 4$ cups per day (RR, 0.8 ; $95 \% \mathrm{CI}, 0.7$ 0.93) might play a role in the prevention of type 2 diabetes. However, no statistically significant association was observed for sex and the follow-up durations stratified between tea consumption and type 2 diabetes.

CONCLUSIONS: This meta-analysis indicates that tea consumption $\geq 4$ cups per day may lower the risk of type 2 diabetes.

KEY WORDS: type 2 diabetes; tea; meta-analysis.

J Gen Intern Med (24)5:557-62

DOI: $10.1007 /$ s11606-009-0929-5

(C) Society of General Internal Medicine 2009

Received August 23, 2008

Revised December 16, 2008

Accepted January 26, 2009

Published online March 24, 2009

\section{INTRODUCTION}

Type 2 diabetes as a public health burden has dramatically increased worldwide. ${ }^{1}$ It is considered as the fifth leading cause of death in the world. The number of diagnosed type 2 diabetes is predicted to reach approximately 366 million by the year $2030 .^{2,3}$ Increasing physical activity and modifying lifestyle have been proved to prevent or delay the incidence of type 2 diabetes. ${ }^{4}$ It has been proposed that chronic oxidative stress as a underlying mechanism in the development of insulin resistance, impaired glucose tolerance, $\beta$-cell dysfunction, and type 2 diabetes. ${ }^{5-7}$ Recent researches have found that green tea has antioxidative, antiinflammatory, and cholesterol-lowering effects. $^{8-10}$

Tea, next only to water, is the most popular consumed beverage in the world with a per capita consumption of $120 \mathrm{ml}$ per day. ${ }^{11}$ Therefore, small effects of tea at a population level would have a large impact on public health. Tea, derived from the plant Camellia sinensis, can be classified into three major types depending on the level of fermentation: green tea (unfermented), oolong tea (partially fermented), and black tea (fermented). ${ }^{12,13}$ The components of each tea are different, which is due to the different producing process. Green tea comes from steamed fresh leaves, which contain more catechins, including epigallocatechin gallate (EGCG), epicatechin-3-gallate (ECG), epigallocatechin (EGC), and epicatechin (EC). ${ }^{14}$ Black tea and oolong tea contain more theaflavins and thearubigins. ${ }^{15}$ In recent years, tea consumption has been extensively studied in relation to various diseases, especially cardiovascular disease and cancer. ${ }^{16-18}$

There is accruing evidence that tea may prevent diabetes. Green tea polyphenols (GTP) have been shown to scavenge free radicals, decrease lipid peroxidation by increasing the activity of superoxide dismutase and glutathione, and also have antidiabetic effects. ${ }^{19}$ EGCG has insulin mimetic effect; it controls gluconeogenesis by inhibiting the expression of genes, such as PEPCK (phosphoenolpyruvate carboxykinase) and G6Pase (glucose-6-phosphatase). It also may promote the phosphorylation of insulin-signaling proteins and enhance insulin activity. ${ }^{20-22}$ Wolfram et al. ${ }^{23}$ indicated that EGCG beneficially improved glucose and lipid metabolism in H4IIE cells and enhanced glucose tolerance in models of diabetes. Green tea extract also could increase fat metabolism and lipolysis in healthy humans. ${ }^{22}$ Another study provided evidence that green tea promoted glucose metabolism in healthy humans and produced an antihyperglycemic effect in diabetic mice. ${ }^{24} \mathrm{~A}$ population-based, case-control study by 
Polychronopoulos et al. $^{25}$ reported that tea consumption could reduce levels of fasting blood glucose in nonobese elderly people.

To our knowledge, several epidemiologic studies ${ }^{25-34}$ have been performed to investigate the association of tea consumption with type 2 diabetes; however, the results of these studies were not entirely consistent: some studies showed that tea consumption might reduce the risk of type 2 diabetes, ${ }^{25,28,29,32-34}$ whereas others found nonsignificant relationships between the two. ${ }^{26,27,30,31}$ Because the relationship between tea consumption and risk of type 2 diabetes is still equivocal, we conducted this meta-analysis to further clarify this association based on the studies from the United States, Europe, and Asian countries.

\section{METHODS}

\section{Study Selection and Data Extraction}

We conducted a systematic literature search of PUBMED, MEDLINE (1966 to November 2008), and EMBASE (1980 to November 2008) to identify relevant studies. The Cochrane Database of Systematic Reviews also was queried. Search terms included tea, coffee, catechin, or flavonoids in combination with diabetes, glucose, and insulin. The search was limited to English-language articles. The titles and abstracts were scanned to exclude studies that were clearly irrelevant. The full texts of the remaining articles were read to determine whether they contained information about our interest. In addition, the electronic searches were supplemented by scanning reference lists from retrieved articles to identify additional studies. All searches were conducted independently by two investigators.

The eligible studies had to fulfill the following criteria: 1) to improve the validity of our results, only cohort studies could be included; 2) there are different types of tea in the world; we only included tea derived from Camellia sinensis; 3) the exposure of interest was tea consumption; and 4) the result of each study was expressed as relative risk (RR) or hazard ratio (HR) together with its corresponding 95\% confidence interval (CI), or sufficient information to calculate. Because this study focused on tea consumption in relation to type 2 diabetes and related outcomes, we excluded studies concerning type 1 diabetes and animal studies.

The primary literature search identified 451 records; 432 articles were excluded after screening titles and abstracts, because they were laboratory studies, review articles, or irrelevant to the current study. Thus, a total of 19 articles were identified. Seven studies were excluded because they were other design types. ${ }^{24,25,35-39}$ A study by Mackenzie et al. ${ }^{40}$ was excluded because some participants had diabetes at baseline. Two articles were excluded because they did not provide $95 \%$ CI or data to calculate (Fig. 1). ${ }^{41,42}$

The first author's name, year of publication, country where the study was performed, age range of study participants, years of follow-up, sample size, diabetes definition/assessment, measurement of tea consumption, different levels of tea consumption of green tea, black tea, and oolong tea, covariates controlled for in the analysis, risk estimates with corresponding 95\% CI, and cohort designation were collected from every included study. If a study provided several risk

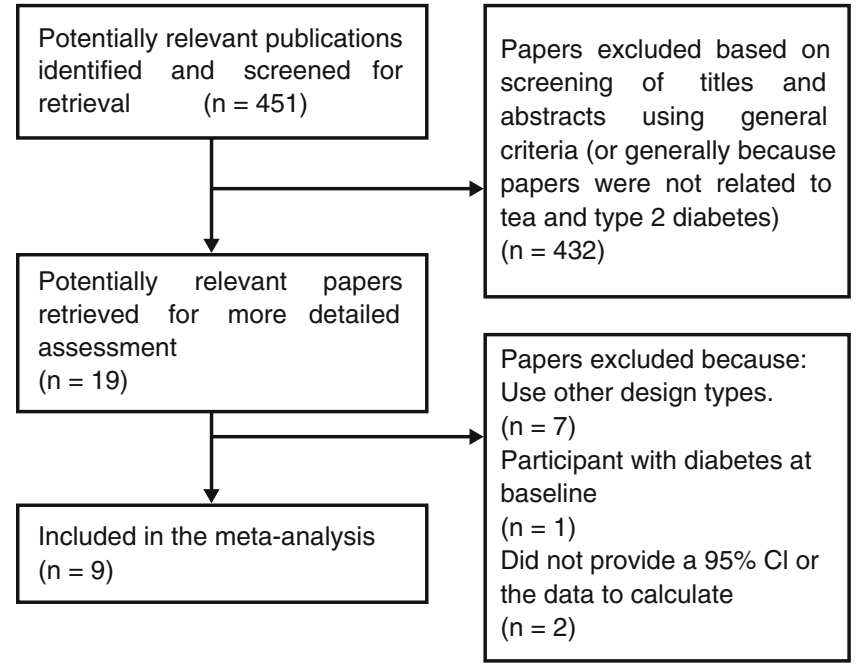

Figure 1. Study flow chart.

estimates, the most completely adjusted estimate was extracted independently by two investigators. Discrepancies were resolved by discussion and repeated examination of the articles.

\section{Quality Assessment}

For measuring quality of observational studies no universal scale was available, therefore, we followed the guidelines of the Meta-analysis Of Observational Studies in Epidemiology (MOOSE) group and assessed the quality of the included studies based on the following criteria: 1) clear description of the population and setting; 2) tea should be derived from Camellia sinensis only; 3) appropriate measurement of outcomes; 4) response rate of the original study was higher than $80 \%$; 5) completeness of follow-up; 6) appropriate consideration and adjustment for potential confounders; 7) <20 percent dropout rate; 8) clear reporting of dropouts; 9) provided data on levels of tea consumption; 10) appropriate statistical and analytical methods. ${ }^{43}$ Throughout this assessment, when information about a specific item was consistent with the criteria, it was scored as "1"; otherwise, it was scored as "0". Studies that fulfilled more than eight criteria were considered high-quality (i.e., scored $\geq 8$ ).

\section{Statistical Analysis}

For meta-analysis, we used RRs as the common risk assessment measurement. We considered hazard ratios as RRs directly. ${ }^{44}$ Study-specific RRs and corresponding 95\% CIs of tea consumption levels were extracted. To obtain a pooled RR and its $95 \% \mathrm{CI}$, the $\log \mathrm{RR}$ were weighted by the inverse of their variances. Pooled relative risks with $95 \%$ CIs were calculated with the method of DerSimonian and Laird random-effects model. ${ }^{45}$ Overall RR and 95\% CI were directly extracted from two studies. ${ }^{28,30}$ In other included studies, we calculated the total RR and 95\% CI with the information provided. In addition, we analyzed tea consumption by men and women separately and distinguished three levels: <1 cup per day; 1-3 cups per day; and $\geq 4$ cups per day. We defined $<1$ cup per day as $>0$ cups per day but $<1$ cup per day. To improve comparability with other studies, we combined 1 cup per day and 2-3 
cups per day into 1-3 cups per day, 1-2 and 2-3 cups per day were considered 1-3 cups per day, and 1-6 cups per week also was considered $<1$ cup per day. ${ }^{26,28,30-32,34}$

We evaluated possible heterogeneity of study results using the $\mathrm{Q}$ test $(P<0.1$ was considered representative of statistically significant heterogeneity) and the $\mathrm{I}^{2}$ statistic. ${ }^{46}$ If significant heterogeneity existed, sensitivity analyses were performed. Funnel plot was used to assess the publication bias and Egger regression test to determine funnel plot asymmetry. We considered $P<0.1$ to indicate a statistically significant publication bias. ${ }^{47}$ All statistical analyses were conducted by using STATA 9.2 software (STATA Corporation, College Station, TX).

\section{RESULTS}

We identified nine cohort studies, including 324,141 participants and 11,400 incident cases of type 2 diabetes with the follow-up ranging from 5 to 18 years (Table 1). ${ }^{26-34}$ Three studies involved women only, and the other six studies included both men and women. Mean age at baseline varied from 26 to 88 years. In our included studies, age, body mass index (BMI), physical activity, diet, inherit education, smoking status, and alcohol intake were considered as potential confounders. Of the nine cohort studies, five ${ }^{26-29,33}$ were performed in the United States, and the remaining four were performed in Finland, ${ }^{30}$ the United Kingdom, ${ }^{31}$ Japan, ${ }^{32}$ and Singapore. ${ }^{34}$ Five studies reported that tea consumption was not statistically significantly associated with risk of type 2 diabetes. ${ }^{26,27,30,31}$ Although Hamer et al. ${ }^{31}$ indicated that intake of $>3$ cups of tea per day was associated with a lower risk of diabetes after adjustment for age, sex, ethnicity, and social status, it was not robust for further adjustment. Two studies $^{29,33}$ revealed that there was a possible reduction for type 2 diabetes with higher tea intake ( $\geq 4$ cups per day) relative to the lower $(<1$ cup per day, $1-3$ cups per day). A

Table 1. Characteristics of Studies Included in the Meta-Analysis

\begin{tabular}{|c|c|c|c|c|c|c|c|}
\hline Source & $\begin{array}{l}\text { Sex/ } \\
\text { Quality } \\
\text { Scores }\end{array}$ & $\begin{array}{l}\text { Age at } \\
\text { Baseline } \\
(y r)\end{array}$ & $\begin{array}{l}\text { Total } \\
\mathrm{N} / \text { No. of } \\
\text { Cases }\end{array}$ & $\begin{array}{l}\text { Mean } \\
\text { Follow-up } \\
\text { (yr) }\end{array}$ & $\begin{array}{l}\text { Type } 2 \text { Diabetes Definition/ } \\
\text { Assessment }\end{array}$ & $\begin{array}{l}\text { Method for } \\
\text { Adjustment }\end{array}$ & Cohort Designation \\
\hline \multirow[t]{2}{*}{$\begin{array}{l}\text { Salazar-Martinez } \\
\text { et al., } 2004^{27} \text {, USA }\end{array}$} & M 9 & $40-75$ & $\begin{array}{c}41,934 / \\
1,311\end{array}$ & 12 & $\begin{array}{l}\text { NDDG diagnostic criteria, } \\
\text { self-report, confirmed by } \\
\text { medical records }\end{array}$ & $\begin{array}{l}\text { Proportional } \\
\text { hazards } \\
\text { regression }\end{array}$ & $\begin{array}{l}\text { The Nurses' Health Study } \\
\text { and Health Professionals' } \\
\text { Follow-up Study }\end{array}$ \\
\hline & F9 & $30-55$ & $\begin{array}{c}84,276 / \\
4,079\end{array}$ & 18 & $\begin{array}{l}\text { NDDG diagnostic criteria, } \\
\text { self-report, confirmed by } \\
\text { medical records }\end{array}$ & $\begin{array}{l}\text { Proportional } \\
\text { hazards } \\
\text { regression }\end{array}$ & $\begin{array}{l}\text { The Nurses' Health Study } \\
\text { and Health Professionals' } \\
\text { Follow-up Study }\end{array}$ \\
\hline $\begin{array}{l}\text { Song et al., } \\
2005^{29} \text {, USA }\end{array}$ & F 9 & $\geq 45$ & $\begin{array}{c}37,457 / \\
1,593\end{array}$ & 8.8 & $\begin{array}{l}\text { ADA diagnostic criteria, } \\
\text { self-report, confirmed from } \\
\text { supplemental questionnaire } \\
\text { and physician } \\
\text { information }\end{array}$ & $\begin{array}{l}\text { Proportional } \\
\text { hazards } \\
\text { regression }\end{array}$ & Women's Health Study \\
\hline $\begin{array}{l}\text { Greenberg et al., } \\
2005^{28} \text {, USA }\end{array}$ & $\mathrm{M} / \mathrm{F} 9$ & $32-88$ & $\begin{array}{c}5,127 / \\
170\end{array}$ & 8.4 & self-report of doctor's diagnosis & $\begin{array}{l}\text { Proportional } \\
\text { hazards } \\
\text { regression }\end{array}$ & $\begin{array}{l}\text { First National Health and } \\
\text { Nutrition Examination } \\
\text { Survey Epidemiologic } \\
\text { Follow Up Study }\end{array}$ \\
\hline $\begin{array}{l}\text { van Dam et al., } \\
2006^{26}, \text { USA }\end{array}$ & F 9 & $26-46$ & $\begin{array}{c}88,259 / \\
1,263\end{array}$ & 10 & $\begin{array}{l}\text { NDDG diagnostic criteria, } \\
\text { self-report, confirmed by } \\
\text { medical record review }\end{array}$ & $\begin{array}{l}\text { Proportional } \\
\text { hazards } \\
\text { regression }\end{array}$ & Nurses' Health Study II \\
\hline $\begin{array}{l}\text { Hu et al., } 2006^{30} \text {, } \\
\text { Finland }\end{array}$ & $\mathrm{M} / \mathrm{F} 9$ & $35-74$ & $\begin{array}{l}21,385 / \\
964\end{array}$ & 13.4 & WHO criteria, NHDR, NSIIDR & $\begin{array}{l}\text { Proportional } \\
\text { hazards } \\
\text { regression }\end{array}$ & 4 surveys in Finland \\
\hline \multirow[t]{2}{*}{$\begin{array}{l}\text { Iso et al., } 2006^{32} \text {, } \\
\text { Japan }\end{array}$} & M 8 & $40-65$ & $\begin{array}{c}6,727 / \\
231\end{array}$ & 5 & $\begin{array}{l}\text { FSG } \geq 7.8 \mathrm{mmol} / \mathrm{L}, \text { or } \\
\mathrm{RM} \geq 11.1 \mathrm{mmol} / \mathrm{L}, \text { or } \\
\text { treatment with oral } \\
\text { hypoglycemic agents or } \\
\text { insulin to indicate new cases } \\
\text { of diabetes, self-report }\end{array}$ & $\begin{array}{l}\text { Multiple logistic } \\
\text { regression }\end{array}$ & $\begin{array}{l}25 \text { communities across } \\
\text { Japan }\end{array}$ \\
\hline & F 8 & $40-65$ & $\begin{array}{l}10,686 / \\
213\end{array}$ & 5 & $\begin{array}{l}\text { FSG } \geq 7.8 \mathrm{mmol} / \mathrm{L}, \text { or } \\
\mathrm{RM} \geq 11.1 \mathrm{mmol} / \mathrm{L}, \text { or treatment } \\
\text { with oral hypoglycemic agents or } \\
\text { insulin to indicate new cases of } \\
\text { diabetes, self-report }\end{array}$ & $\begin{array}{l}\text { Multiple logistic } \\
\text { regression }\end{array}$ & $\begin{array}{l}25 \text { communities across } \\
\text { Japan }\end{array}$ \\
\hline $\begin{array}{l}\text { Pereira et al., } \\
2006^{33} \text {, USA }\end{array}$ & F 9 & 55-69 & $\mathrm{N} / \mathrm{A}$ & 11 & $\begin{array}{l}4 \text { follow-up mailed surveys, } \\
\text { self-report }\end{array}$ & $\begin{array}{l}\text { Proportional } \\
\text { hazards } \\
\text { regression }\end{array}$ & $\begin{array}{l}\text { Iowa Women's Health } \\
\text { Study }\end{array}$ \\
\hline $\begin{array}{l}\text { Hamer et al., } \\
2008^{31} \text {, } \\
\text { United Kingdom }\end{array}$ & M/F 9 & $35-55$ & $\begin{array}{c}5,823 / \\
387\end{array}$ & 11.7 & $\begin{array}{l}\text { OGTT, diabetic medication, } \\
\text { self-report of doctor's } \\
\text { diagnosis }\end{array}$ & $\begin{array}{l}\text { Proportional } \\
\text { hazards } \\
\text { regression }\end{array}$ & Whitehall II cohort \\
\hline $\begin{array}{l}\text { Odegaard Ao } \\
\text { et al., } 2008^{34} \text {, } \\
\text { Singapore }\end{array}$ & $\mathrm{M} / \mathrm{F} 9$ & $45-74$ & $\begin{array}{c}22,467 / \\
1,189\end{array}$ & 5.7 & DRICD codes, Telephone interview & $\begin{array}{l}\text { Proportional } \\
\text { hazards } \\
\text { regression }\end{array}$ & $\begin{array}{l}\text { The Singapore Chinese } \\
\text { Health Study }\end{array}$ \\
\hline
\end{tabular}

Abbreviations: NHDR, National Hospital Discharge Register; NSIIDR, National Social Insurance Institution's Drug Register; OGTT, oral glucose tolerance test; N/A, information not available; ADA, American Diabetes Association; NDDG, National Diabetes Data Group; FSG, fasting serum glucose concentration; RM, randomly measured concentration; WHO, World Health Organization; DRICD, codes, diabetes-related International Classification of Diseases codes 
recent study performed in Singapore ${ }^{34}$ reported that black tea was potentially associated with a lower risk of type 2 diabetes; however, Iso et al. ${ }^{32}$ reported that only consumption of green tea was associated with a reduced risk for type 2 diabetes. The study by Greenberg et al. ${ }^{28}$ reported that the inverse association existed in the 60 years and younger age group.

According to the generic quality grading for all included studies, they were evaluated as high quality. The summary relative risk of type 2 diabetes was 0.96 (95\% CI, 0.92-1.01), which did not show that tea consumption was associated with decreased risk of type 2 diabetes. There was no statistically significant heterogeneity among studies $(\mathrm{Q}=6.37 ; P=0.61$; $\mathrm{I}^{2}=0 \%$ ). However, visualization of the funnel plot (Fig. 2) and Egger's test $(P=0.05)$ revealed some publication bias.

We also conducted stratified analyses of sex, follow-up years, and daily tea consumption. Compared with those who never drink tea, the analysis of daily tea consumption revealed that there are statistically significant effects for tea intake $\geq 4$ cups per day (RR, 0.8; 95\% CI, 0.7-0.93; Fig. 3). For $<1$ cup per day (RR, 0.99; 95\% CI, 0.94-1.05) and 1-3 cups per day (RR, 0.99; 95\% CI, 0.93-1.05), we did not find any statistical significance. The distinction among green tea, black tea, and oolong tea might be relevant for risk of type 2 diabetes, so we intended to abstract data from included studies; however, only one study provided information on tea types, ${ }^{32}$ therefore, we were not able to conduct stratified analysis on tea types. For sex and follow-up duration stratified analyses, no statistically significant association was observed: male (RR, 0.94; 95\% CI, 0.86-1.02), female (RR, 0.94; 95\% CI, 0.86-1.04); and followup durations: <10 years (RR, 0.94; 95\% CI, 0.86-1.03), $\geq 10$ years (RR, 0.97; 95\% CI, 0.92-1.02).

\section{DISCUSSION}

To our knowledge, this is the first meta-analysis to evaluate the association between tea consumption and the risk of type 2 diabetes. Our study, based on nine cohort studies, showed that participants who drank four or more cups of tea per day had a $20 \%$ lower risk of type 2 diabetes compared with those who drank less or none. However, no statistically significant association was observed for sex and the follow-up durations

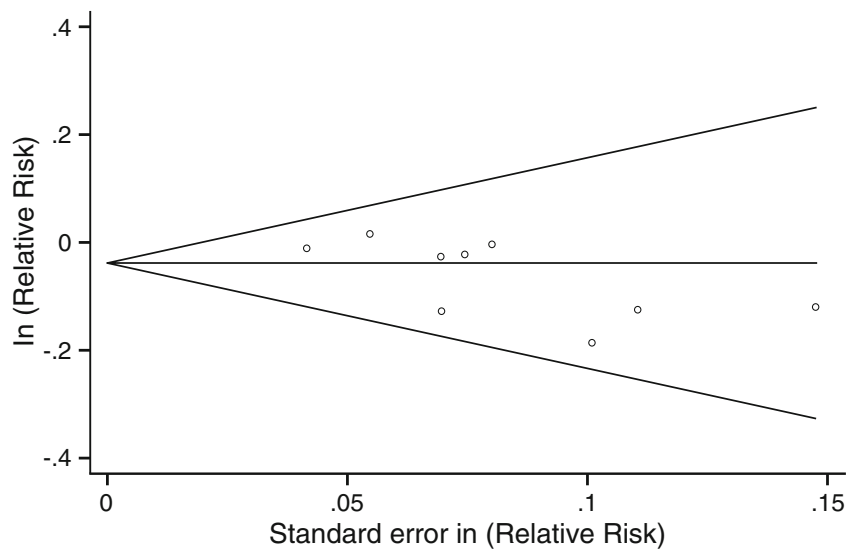

Figure 2. Begg's funnel plot of tea consumption and type 2 diabetes risks.

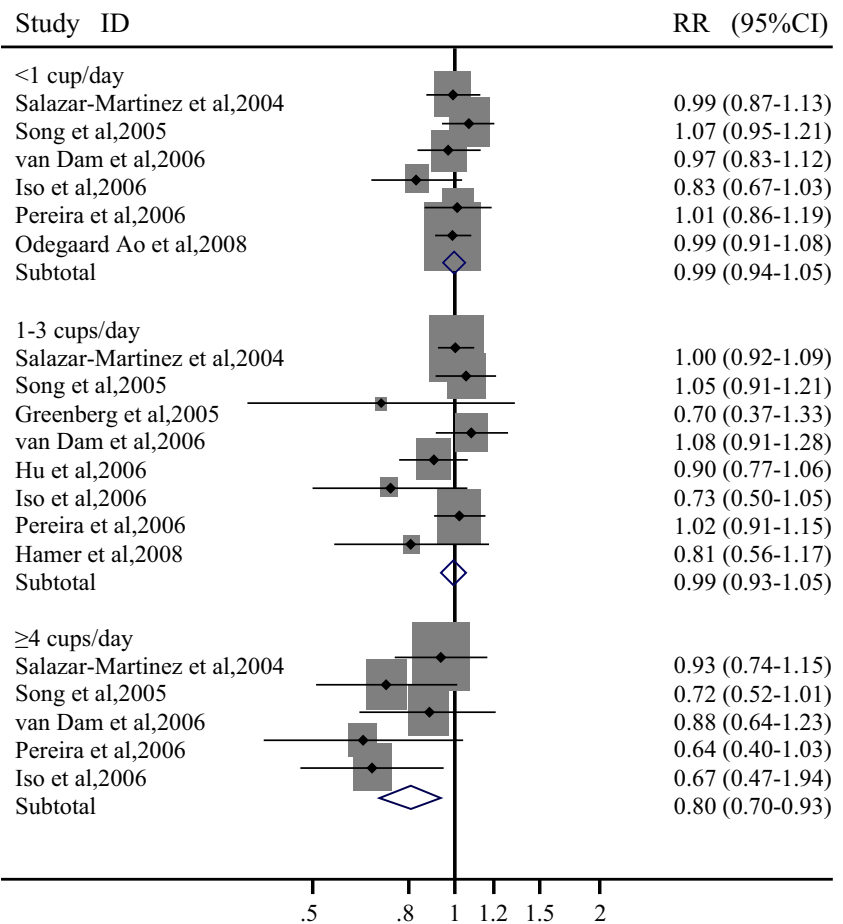

Figure 3. Stratified analysis pooled relative risks of type 2 diabetes on daily tea consumption. All the three levels were compared to those who never drinking tea. The area of the squares reflects the study-specific weight (i.e., inverse of the variance). The diamond represents the pooled relative risk and $95 \%$ confidence interval of every subgroup.

stratified between tea consumption and type 2 diabetes. In the absence of larger population-based, long-term, randomized, intervention studies, our study is the best available evidence.

This study showed that relatively high tea intake could lower the risk of type 2 diabetes. This could be a dose-response effect. Many researches have certified that the main extracts of tea have antidiabetes effects. One study reported that green tea extract (300 mg/kg BW/day) could significantly decrease blood glucose in rats. ${ }^{48} \mathrm{Wu}$ et al. revealed that ingestion of $0.5 \mathrm{~g}$ per day of green tea could significantly reduce fasting hyperglycemia compared with the control group in a fructose-fed rat model. They also found that daily supplementation of $0.5 \mathrm{~g}$ of green tea for 12 weeks could reduce fasting plasma glucose levels, insulin, triglyceride, and free fatty acids in Sprague-Dawley rats. ${ }^{49,50}$ Islam et al. reported that green tea intake of $23 \mathrm{~g}$ per day could increase serum insulin concentration in rats, and higher consumption of green tea can be beneficial for normal human subjects with hyperlipidemia. ${ }^{51}$ Therefore, certain doses of green tea were beneficial for diabetes prevention.

Multiple etiological risk factors for diabetes have been identified, such as family history, genetic alteration, environmental factor, lifestyle, and physical activities. Genetic and lifestyle factors may influence the effect of tea consumption in the process of diabetes, and these factors were not completely controlled in all of our included studies, therefore, it was not easy to make a definitive conclusion. Further epidemiologic studies are required.

Several potential limitations of this meta-analysis must be considered when interpreting the results. First, our search was 
restricted to studies published in indexed journals. There lacked more unpublished studies with negative results and we only included papers published in English languages, which would be the source of our publication bias. Moreover, the small sample size of our meta-analysis for evaluating the association between tea consumption with type 2 diabetes risk may reduce the power of any test to detect publication bias. Also, because no universally validated scale of study quality exists, we used a scale of items that were selected based on common sense only. A different scale may have yielded other results. Second, most of our included studies were not originally designed to test the tea/type 2 diabetes hypothesis and methods for measuring tea intake differed across studies, which may influence our results. Third, information from articles was limited: we cannot conduct stratified analysis on green tea, black tea, and oolong tea consumption with type 2 diabetes risk. Finally, our analysis was based on observational studies and we cannot exclude uncontrolled confounders as a potential explanation for the observed association. There was a lack of adjustment for socioeconomic status (only 5 studies adjusted for socioeconomic status or education), which could contribute to a noncausal association between tea consumption and diabetes, because low socioeconomic status is related to depression and other factors, which will increase the risk for type 2 diabetes. ${ }^{52-54}$

\section{CONCLUSIONS}

This study indicates that tea consumption $\geq 4$ cups per day may lower the risk of type 2 diabetes. However, the reasons for this remain unclear; therefore, it is too early to recommend that the public drink more tea. Larger, population-based, randomized, controlled trials are required to further clarify the relationship between tea consumption and the risk of type 2 diabetes.

Acknowledgments: This work was supported by grants from the National Natural Science Foundation of China (No 30671004), "973 Project" (2006CB503902), and the Natural Science Foundation of Jiangsu Province (No BK2006006).

Conflict of Interest: None disclosed.

Corresponding Author: Dalong Zhu, MD, PhD; Department of Endocrinology, Drum Tower Clinical Medical College of Nanjing Medical University, 321 Zhongshan Road, Nanjing 210008, Jiangsu Province, China (e-mail: zhudldr@gmail.com).

\section{REFERENCES}

1. King H, Aubert RE, Herman WH. Global burden of diabetes, 19952025: prevalence, numerical estimates, and projections. Diabetes Care. 1998; 21: 1414-31.

2. Zimmet $\mathbf{P}$. The burden of type 2 diabetes: are we doing enough. Diabetes Metab. 2003; 29: 6S9-18.

3. Wild S, Roglic G, Green A, Sicree R, King H. Global prevalence of diabetes: estimates for the year 2000 and projections for 2030. Diabetes Care. 2004; 27: 1047-53.

4. Hu FB, Manson JE, Stampfer MJ. Diet, lifestyle, and the risk of type 2 diabetes mellitus in women. N Engl J Med. 2001; 345: 790-7.
5. Robertson R, Zhou H, Zhang T, Harmon JS. Chronic oxidative stress as a mechanism for glucose toxicity of the beta cell in type 2 diabetes. Cell Biochem Biophys. 2007; 48: 139-46.

6. Wright $\mathbf{E} \mathbf{J r}$, Scism-Bacon JL, Glass LC. Oxidative stress in type 2 diabetes: the role of fasting and postprandial glycaemia. Int $\mathrm{J}$ Clin Pract. 2006; 60: 308-14.

7. Ceriello A, Motz E. Is oxidative stress the pathogenic mechanism underlying insulin resistance, diabetes, and cardiovascular disease? The common soil hypothesis revisited. Arterioscler Thromb Vasc Biol. 2004; 24: 816-23.

8. Dona M, Dell'Aica I, Calabrese F, et al. Neutrophil restraint by green tea: inhibition of inflammation, associated angiogenesis, and pulmonary fibrosis. J Immunol. 2003; 170: 4335-41.

9. Osada K, Takahashi M, Hoshina S, Nakamura M, Nakamura S, Sugano M. Tea catechins inhibit cholesterol oxidation accompanying oxidation of low density lipoprotein in vitro. Comp Biochem Physiol Part C Toxicol Pharmacol. 2001; 128: 153-64.

10. Raederstorff DG, Schlachter MF, Elste V, Weber P. Effect of EGCG on lipid absorption and plasma lipid levels in rats. J Nutr Biochem. 2003; 14: 326-32.

11. McKay DL, Blumberg JB. The role of tea in human health: an update. J Am Coll Nutr. 2002; 21: 1-13.

12. Cheng TO. All teas are not created equal the Chinese green tea and cardiovascular health. Int J Cardiol. 2006; 108: 301-8.

13. Blumberg $\mathbf{J}$. Introduction to the proceedings of the third international scientific symposium on tea and human health: role of flavonoids in the diet. J Nutr. 2003; 133: 3244S-3246S.

14. Graham HN. Green tea composition, consumption, and polyphenol chemistry. Prev Med. 1992; 21: 334-50.

15. Balentine DA, Wiseman SA, Bouwens LC. The chemistry of tea flavonoids. Crit Rev Food Sci Nutr. 1997; 37: 693-704.

16. Peters U, Poole C, Arab L. Does tea affect cardiovascular disease? A meta-analysis. Am J Epidemiol. 2001; 154: 495-503.

17. Sun CL, Yuan JM, Koh WP, Yu MC. Green tea, black tea and colorectal cancer risk: a meta-analysis of epidemiologic studies. Carcinogenesis. 2006; 27: 1301-9.

18. Nakachi K, Matsuyama S, Miyake S, Suganuma M, Imai K. Preventive effects of drinking green tea on cancer and cardiovascular disease: epidemiological evidence for multiple targeting prevention. BioFactors. 2000; 13: 49-54

19. Sabu MC, Smitha K, Kuttan R. Anti-diabetic activity of green tea polyphenols and their role in reducing oxidative stress in experimental diabetes. J Ethnopharmacol. 2002; 83: 109-16.

20. Waltner-Law ME, Wang XL, Law BK, Hall RK, Nawano M, Granner DK. Epigallocatechin gallate, a constituent of green tea, represses hepatic glucose production. J Biol Chem. 2002; 277: 34933-40.

21. Anderson RA, Polansky MM. Tea enhances insulin activity. J Agric Food Chem. 2002; 50: 7182-6.

22. Venables MC, Hulston CJ, Cox HR, Jeukendrup AE. Green tea extract ingestion, fat oxidation, and glucose tolerance in healthy humans. Am J Clin Nutr. 2008; 87: 778-84.

23. Wolfram S, Raederstorff D, Preller M. Epigallocatechin gallate supplementation alleviates diabetes in rodents. J Nutr. 2006; 136: 2512-8.

24. Tsuneki H, Ishizuka M, Terasawa M, Wu JB, Sasaoka T, Kimura I. Effect of green tea on blood glucose levels and serum proteomic patterns in diabetic $(\mathrm{db} / \mathrm{db})$ mice and on glucose metabolism in healthy humans. BMC Pharmacology. 2004; 4: 18.

25. Polychronopoulos E, Zeimbekis A, Kastorini CM, Papairakleous N, Vlachou I, Bountziouka V, Panagiotakos DB. Effects of black and green tea consumption on blood glucose levels in non-obese elderly men and women from Mediterranean Islands (MEDIS epidemiological study). Eur J Nutr. 2008; 47: 10-6.

26. van Dam RM, Willett WC, Manson JE, Hu FB. Coffee, caffeine, and risk of type 2 diabetes: a prospective cohort study in younger and middleaged U.S. women. Diabetes Care. 2006; 29: 398-403.

27. Salazar-Martinez E, Willett WC, Ascherio A, et al. Coffee consumption and risk for type 2 diabetes mellitus. Ann Intern Med. 2004; 140: 1-8.

28. Greenberg JA, Axen KV, Schnoll R, Boozer CN. Coffee, tea and diabetes: the role of weight loss and caffeine. Int $J$ Obes. 2005; 29: 1121-9.

29. Song Y, Manson JE, Buring JE, Sesso HD, Liu S. Associations of dietary flavonoids with risk of type 2 diabetes, and markers of insulin resistance and systemic inflammation in women: a prospective study and cross-sectional analysis. J Am Coll Nutr. 2005; 24: 376-84.

30. Hu G, Jousilahti P, Peltonen M, Bidel S, Tuomilehto J. Joint association of coffee consumption and other factors to the risk of type 2 diabetes: a prospective study in Finland. Int $\mathrm{J}$ Obes (Lond). 2006; 30 : $1742-9$. 
31. Hamer M, Witte DR, Mosdøl A, Marmot MG, Brunner EJ. Prospective study of coffee and tea consumption in relation to risk of type 2 diabetes mellitus among men and women: The Whitehall II study. $\mathrm{Br} \mathrm{J}$ Nutr. 2008; 4: 1-8.

32. Iso H, Date C, Wakai K, Fukui M, Tamakoshi A; JACC Study Group. The relationship between green tea and total caffeine intake and risk for self-reported type 2 diabetes among Japanese adults. Ann Intern Med. 2006; 144:554-62.

33. Pereira MA, Parker ED, Folsom AR. Coffee consumption and risk of type 2 diabetes mellitus: an 11-year prospective study of 28812 postmenopausal women. Arch Intern Med. 2006; 166: 1311-6.

34. Odegaard AO, Pereira MA, Koh WP, Arakawa K, Lee HP, Yu MC. Coffee, tea, and incident type 2 diabetes: the Singapore Chinese Health Study. Am J Clin Nutr. 2008; 88: 979-85.

35. Yamaji T, Mizoue T, Tabata $\mathbf{S}$, et al. Coffee consumption and glucose tolerance status in middle-aged Japanese men. Diabetologia. 2004; 47: 2145-51.

36. MacKenzie T, Comi R, Sluss $\mathbf{P}$, et al. Metabolic and hormonal effects of caffeine: randomized, double-blind, placebo-controlled crossover trial. Metabolism. 2007; 56: 1694-8.

37. Fukino Y, Shimbo M, Aoki N, Okubo T, Iso H. Randomized controlled trial for an effect of green tea consumption on insulin resistance and inflammation markers. J Nutr Sci Vitaminol. 2005; 51: 335-42.

38. Hosoda K, Wang MF, Liao ML, et al. Antihyperglycemic effect of oolong tea in type 2 diabetes. Diabetes Care. 2003; 26: 1714-8.

39. Ryu OH, Lee J, Lee KW, et al. Effects of green tea consumption on inflammation, insulin resistance and pulse wave velocity in type 2 diabetes patients. Diabetes Res Clin Pract. 2006; 71: 356-8.

40. Mackenzie T, Leary L, Brooks WB. The effect of an extract of green and black tea on glucose control in adults with type 2 diabetes mellitus: double-blind randomized study. Metabolism. 2007; 56: 1340-4.

41. Nettleton JA, Harnack LJ, Scrafford CG, Mink PJ, Barraj LM, Jacobs DR Jr. Dietary flavonoids and flavonoid-rich foods are not associated with risk of type 2 diabetes in postmenopausal women. J Nutr. 2006; 136: 3039-45.
42. Hodge AM, English DR, O'Dea K, Giles GG. Dietary patterns and diabetes incidence in the Melbourne Collaborative Cohort Study. Am J Epidemiol. 2007; 165: 603-10.

43. Stroup DF, Berlin JA, Morton SC, et al. Meta-analysis of observational studies in epidemiology: a proposal for reporting. Meta-analysis of observational studies in epidemiology (MOOSE) group. JAMA. 2000; 283: 2008-12

44. Willi C, Bodenmann P, Ghali WA, Faris PD, Cornuz J. Active smoking and the risk of type 2 diabetes: a systematic review and meta-analysis. JAMA. 2007; 298: 2654-64.

45. DerSimonian R, Laird N. Meta-analysis in clinical trials. Control Clin Trials. 1986; 7: 177-88.

46. Higgins JP, Thompson SG. Quantifying heterogeneity in a metaanalysis. Stat Med. 2002; 21: 1539-58.

47. Egger M, Davey Smith G, Schneider M, Minder C. Bias in metaanalysis detected by a simple, graphical test. BMJ. 1997; 315: 629-34.

48. Babu PV, Sabitha KE, Shyamaladevi CS. Therapeutic effect of green tea extract on oxidative stress in aorta and heart of streptozotocin diabetic rats. Chem Biol Interact. 2006; 162: 114-20.

49. Wu LY, Juan CC, Hwang LS, Hsu YP, Ho PH, Ho LT. Green tea supplementation ameliorates insulin resistance and increases glucose transporter IV in a fructose-fed rat model. Eur J Nutr. 2004; 43: $116-24$

50. Wu LY, Juan CC, Ho LT, Hsu YP, Hwang LS. Effect of green tea supplementation on insulin sensitivity in Sprague-Dawley rats. J Agric Food Chem. 2004; 52: 643-8.

51. Islam MS, Choi H. Green tea, anti-diabetic or diabetogenic: a dose response study. BioFactors. 2007; 29: 45-53.

52. Chen R. Green tea, coffee, and diabetes. Ann Intern Med. 2006; 145: 633.

53. Chen R, Wei L, Hu Z, gin X, Copeland JR, Hemingway H. Depression in older people in rural China. Arch Intern Med. 2005; 165: 2019-25.

54. Knol MJ, Twisk JW, Beekman AT, Heine RJ, Snoek FJ, Pouwer F. Depression as a risk factor for the onset of type 2 diabetes mellitus. A meta-analysis. Diabetologia. 2006; 49: 837-45. 